\title{
Anion-Channel Blockade With Alinidine: A Specific Bradycardic Drug for Coronary Heart Disease Without Negative Inotropic Activity?
}

\author{
BRIAN E. JASKI, MD, and PATRICK W. SERRUYS, MD
}

In 14 patients undergoing cardiac catheterization for suspected coronary artery disease, alinidine, 0.6 $\mathrm{mg} / \mathbf{k g}$, was administered intravenously to determine its effects on left ventricular (LV) function, coronary blood flow and myocardial oxygen consumption. To assess effects independent of changes in heart rate (HR), measurements were made at spontaneous and matched pacing HRs. At spontaneous HR, alinidine decreased HR from $70 \pm 2$ to $61 \pm 3$ beats/ $\min \left(p<10^{-6}\right)$. Peak rate of $L V$ pressure decreased from $1,652 \pm 92$ to $1,371 \pm 80 \mathrm{~mm} \mathrm{Hg} / \mathrm{s}\left(p<10^{-5}\right)$ and Vmax decreased from $47 \pm 3$ to $41 \pm 2 \mathrm{~s}^{-1}$ ( $\mathrm{p}$ $\left.<10^{-4}\right)$. Coronary sinus blood flow decreased from $109 \pm 9$ to $89 \pm 7 \mathrm{ml} / \mathrm{min}(\mathrm{p}<0.01)$ and myocardial oxygen consumption from $10.9 \pm 1.0$ to $9.0 \pm 0.8$ $\mathrm{ml} \mathrm{O} / \mathrm{min}(\mathrm{p}<0.05)$. At a matched pacing HR of 98 \pm 3 beats $/ \mathrm{min}$ before and after alinidine administration, peak rate of LV pressure decreased from $1,984 \pm 124$ to $1,793 \pm 106 \mathrm{~mm} \mathrm{Hg} / \mathrm{s}\left(p<10^{-4}\right)$ and Vmax from $60 \pm 5$ to $56 \pm 4 \mathrm{~s}^{-1}(p<0.02)$. Coronary sinus blood flow and myocardial oxygen consumption were not signiflcantly changed at matched pacing HRs. The time constant of the first $40 \mathrm{~ms}$ of $L V$ isovolumic relaxation was prolonged by alinidine only during spontaneous HR. Thus, alinidine results in a bradycardia-dependent decrease in myocardial oxygen consumption. It has negative inotropic properties independent of changes in HR and so is not a pure bradycardia-specific agent.

(Am J Cardiol 1985;56:270-275)
Alinidine is a new bradycardic agent that acts without $\beta$-receptor blockade. ${ }^{1,2}$ As such, use of alinidine could avoid limitations associated with potentially undesirable properties of $\beta$-receptor blockade. ${ }^{3}$ Although its chemical structure is similar to that of clonidine, its pharmacologic spectrum of action is distinctly different with minimal, if any, vasodilating activity. ${ }^{1}$ Millar and Vaughan Williams proposed that its bradycardic action may be mediated by a unique mechanism of anion-selective membrane channel blockade.,5 In in vitro models, alinidine has slowed the rate of sinus node discharge, ${ }^{1,4}$ an in animals, decreased resting myocardial oxygen consumption $\left(\mathrm{MVO}_{2}\right){ }^{5,6}$ In patients with cor-

From the Thoraxcenter, Erasmus University, P.O. Box 1738, 3000 DR Rotterdam, The Netherlands. Dr. Jaski is supported by Training Grant 5-T32-HLD-7049 from the National Institutes of Health, Bethesda, Maryland. His present address: Cardiovascular Division, Brigham and Women's Hospital, Boston, Massachusetts. Manuscript received September 17, 1984; revised manuscript received March 12, 1985, accepted March 20, 1985.

Address for reprints: Patrick W. Serruys, MD, Catheterization Laboratory, Thoraxcenter, P.O. Box 1738, The Netherlands. onary artery disease limited by angina, alinidine decreases heart rate (HR) at rest, prolongs the duration of exercise and increases the level of maximal work without symptoms. ${ }^{7,8}$

Even if alinidine acts through a new mechanism of anion-channel blockade, then it still must be determined whether the drug acts as a unique specific bradycardic agent. Controversy exists over whether alinidine, in humans, has negative inotropic properties as well. ${ }^{9,10}$ Because changes in HR alone may alter global left ventricular (LV) function and metabolism, the direct effects of alinidine on the heart, other than bradycardia, are uncertain.

Therefore, we assessed the acute hemodynamic and myocardial effects of an intravenous dose of alinidine in 14 patients undergoing routine catheterization for evaluation of suspected coronary artery disease. Indexes of $\mathrm{LV}$ function, $\mathrm{MVO}_{2}$ and coronary blood flow were measured before and after administration of the drug. To assess the effects of alinidine independent of changes in HR, measurements were also made at multiple matched atrial paced HRs. 


\section{Methods}

Study population (Table I): The mean age of the patients was $54 \pm 3$ years and mean angiographic ejection fraction was $55 \pm 4 \%$. Two patients with atypical chest pain had normal corongmy anteries. Detaluivining and vasouliating drugs were discontinued at least 24 hours before study. Patients were studied after an overnight fast without premedication preceding routine diagnostic angiography.

Data collection: Catheterization was performed through a right brachial or right femoral approach. In 13 patients, a No. $8 \mathrm{Fr}$ double micromanometer-tipped catheter (Millar Instruments) was advanced into the left ventricle. In 1 patient, an $8 \mathrm{Fr}$ pigtail micromanometer-tipped catheter (Millar Instruments) was advanced into the left ventricle and briefly pulled back to the central aortic position during coronary blood flow measurements and then reintroduced. LV pressure was analyzed using a previously described on-line system to measure the following variables ${ }^{11}$ : HR, LV peak systolic pressure, end-diastolic pressure, peak positive and negative rates of $\mathrm{LV}$ pressure change $(+\mathrm{dP} / \mathrm{dt}$ and $-\mathrm{dP} / \mathrm{dt})$, velocity of the contractile element $(\mathrm{dP} / \mathrm{dt} / \mathrm{P})$ at a total pressure of 40 $\mathrm{mm} \mathrm{Hg}\left(\mathrm{Vce}_{40}\right)$, peak measured velocity of the contractile element (peak Vce), Vce linearly extrapolated to $0 \mathrm{~mm} \mathrm{Hg}$ (Vmax), and $\mathrm{T}_{1}$ and $\mathrm{T}_{2}$, the 2 respective time constants for the early first $40 \mathrm{~ms}$ and late subsequent phases of $\mathrm{LV}$ isovolumic relaxation after the occurrence of peak $-\mathrm{dP} / \mathrm{dt}^{12}$ Mean aortic pressure (MAP) was determined by digital integration. The systolic pressure-rate product was calculated as $\mathrm{HR} \times \mathrm{LV}$ sys (beats/min.mm $\mathrm{Hg}$ ).

A coronary sinus thermodilution catheter (Webster) was placed in the coronary sinus for measurement of coronary blood flow, withdrawal of coronary venous samples and atrial pacing. Coronary sinus flow (CSF) was determined by the thermodilution method of Ganz. ${ }^{13}$ Coronary vascular resistance ( $R$ ) was calculated as MAP/CSF. Aortic arterial (Ao) and coronary sinus (CS) oxygen saturation were measured by oximetry. $\mathrm{MVO}_{2}$ was calculated as $\mathrm{CSF} \times(\mathrm{Ao}-\mathrm{CS}) \times$ hemoglobin concentration (in $\mathrm{g} / \mathrm{dl}) \times 0.0136$. Alinidine serum concentration was measured by radioimmunoassay by the method of Arndts and Stähle. ${ }^{14}$

Protocol: After placement of catheters, stable repeated LV pressures were measured and control coronary blood flow, oxygen saturations, and aortic pressure measurements were made. Control LV pressure measurements were then obtained at spontaneous HR followed by increasing atrial paced HRs with increments of 5 to 10 beats/min between measurements. A maximal $H R$ approximately 30 beats/min greater than the heart rate at rest was chosen to provide a range of HRs and minimize the likelihood of angina pectoris or atrioventricular block. At the maximal paced HR, coronary blood flow, oxygen saturations, and aortic pressures were determined. Pacing was discontinued and repeat control measurements made at a spontaneous HR. Alinidine, $0.6 \mathrm{mg} / \mathrm{kg}$, was then administered by a slow intravenous infusion over 3 minutes. LV measurements were made every 30 seconds for 4 minutes, coronary blood flow, oxygen saturations, and aortic pressures were determined, and a final set of spontaneous HR-LV measure ments were made. An arterial sample was withdrawn to measure alinidine serum concentration. Patients were again atrial paced at increasing HRs with increments of 5 to 10 beats/min with measurements made at each $H R$ up to an identical maximal paced HR as during the pacing measurements before alinidine. At this rate, coronary blood flow, oxygen saturations and aortic pressure were finally determined.

Analysis: Pressure measurements suitable for analysis were recorded in 13 patients. In each patient, comparisons before
TABLE I Patient Characteristic Data

\begin{tabular}{rccc}
\hline Pt & $\begin{array}{c}\text { Age (yr) } \\
\text { \& Sex }\end{array}$ & EF & $\begin{array}{c}\text { No. of Vessels } \\
\text { with }>50 \% \text { Stenoses }\end{array}$ \\
\hline 1 & $27 \mathrm{M}$ & & 3 \\
2 & $47 \mathrm{Ni}$ & 0.64 & 1 \\
3 & $40 \mathrm{~F}$ & 0.60 & 1 \\
4 & $70 \mathrm{~F}$ & $*$ & 2 \\
5 & $47 \mathrm{M}$ & 0.69 & 0 \\
6 & $54 \mathrm{M}$ & 0.56 & 1 \\
7 & $69 \mathrm{M}$ & 0.36 & 3 \\
8 & $51 \mathrm{~F}$ & 0.65 & 0 \\
9 & $49 \mathrm{M}$ & 0.64 & 3 \\
10 & $73 \mathrm{~F}$ & 0.16 & 3 \\
11 & $48 \mathrm{M}$ & 0.47 & 2 \\
12 & $57 \mathrm{M}$ & 0.66 & 3 \\
13 & $69 \mathrm{~F}$ & 0.59 & 3 \\
14 & $60 \mathrm{M}$ & 0.64 & 3 \\
\hline
\end{tabular}

* No EF available because of ventricular ectopic activity during left ventriculoanglogram.

$E F=$ ejection fraction.

and after the administration of alinidine were made at the spontaneous HR and at the minimal (low matched pacing, $\mathrm{P}_{1}$ ) and maximum (high matched pacing, $\mathrm{P}_{2}$ ) identical paced rates obtained before and after the drug. Coronary blood flow and $\mathrm{MVO}_{2}$ could be measured in 12 patients and were compared at spontaneous $\mathrm{HR}$ and matched maximal paced rate.

Statistics: Results are expressed as the mean \pm standard error of the mean. Group data before and after alinidine administration were compared by a paired Student $t$ test. A p value $<0.05$ was considered statistically significant.

\section{Results}

Spontaneous heart rate (Tables II and III): $A$ mean of $9.3 \pm 0.4$ minutes after administration, HR decreased from $70 \pm 2$ to $61 \pm 3$ beats/min $(-12.9 \%$, $p$ $<10^{-6}$ ). LV systolic pressure decreased from $146 \pm 5$ to $140 \pm 6 \mathrm{~mm} \mathrm{Hg}(4.1 \%, \mathrm{p}<0.05)$ and LV end-diastolic pressure increased slightly, from $17.8 \pm 2.2$ to $19.2 \pm 2.4$ $\mathrm{mm} \mathrm{Hg}(7.9 \%, \mathrm{p}<0.05)$. The rate-pressure product decreased from $10.2 \pm 0.4$ to $8.6 \pm 0.6 \times 10^{3}$ beats $/ \mathrm{min} \cdot \mathrm{mm}$ $\mathrm{Hg}\left(-15.7 \%, \mathrm{p}<10^{-5}\right)$.

$\mathrm{LV}$ peak $+\mathrm{dP} / \mathrm{dt}$ fell from $1,652 \pm 92$ to $1,371 \pm 80$ $\mathrm{mm} \mathrm{Hg} / \mathrm{s}\left(17.0 \%, \mathrm{p}<10^{-5}\right)$. Vce 40 decreased $15.6 \%$, peak Vce decreased $17.1 \%$, and Vmax decreased $12.8 \%$; all of these changes were statistically significant compared with control. $\mathrm{LV}$ peak - dP/dt decreased from $1,950 \pm 96$ to $1,845 \pm 106 \mathrm{~mm} \mathrm{Hg} / \mathrm{s}(6.1 \%, \mathrm{p}<0.01)$. The time constants of isovolumic relaxation, $T_{1}$ and $\mathrm{T}_{2}$, increased $12.2 \%(\mathrm{p}<0.001)$ and $10.5 \%(\mathrm{p}<0.01)$, respectively.

During CS flow measurements, CS flow fell from 109 \pm 9 to $89 \pm 7 \mathrm{ml} / \mathrm{min}(-18.3 \%, \mathrm{p}<0.02)$. $\mathrm{MVO}_{2} \mathrm{de}-$ creased significantly, from $10.9 \pm 1.0$ to $9.0 \pm 0.8 \mathrm{ml}$ $\mathrm{O}_{2} / \min (17.4 \%, \mathrm{p}<0.05)$.

Mean alinidine serum concentration determined preceding the final atrial pacing in 12 patients was 790 $\pm 112 \mathrm{ng} / \mathrm{ml}$.

Matched atrial pacing (Tables II and III): Low matched pacing rate $\left(P_{1}\right)$ : At a matched pacing rate of $74 \pm 3$ beats $/ \mathrm{min}$ before and after alinidine administration, $\mathrm{LV}+\mathrm{dP} / \mathrm{dt}$ decreased from $1,681 \pm 89$ to 1,479 $\pm 76 \mathrm{~mm} \mathrm{Hg} / \mathrm{s}\left(12.0 \%, \mathrm{p}<10^{-5}\right) . \mathrm{LV}-\mathrm{dP} / \mathrm{dt}$ decreased 
TABLE II Left Ventricular Function During Control and After Alinidine Administration

\begin{tabular}{|c|c|c|c|c|c|}
\hline & & Control & Alinidine & $\Delta \%$ & p Value \\
\hline HR (beats/min) & $\begin{array}{l}S \\
P 1 \\
P 2\end{array}$ & $\begin{array}{l}70 \pm 2 \\
74 \pm 3 \\
98 \pm 3\end{array}$ & $\begin{array}{l}61 \pm 3 \\
74 \pm 3 \\
98 \pm 3\end{array}$ & $\begin{array}{c}-12.9 \\
0 \\
0\end{array}$ & $\begin{array}{r}<10^{-6} \\
N S \\
N S\end{array}$ \\
\hline LVsys (mm Hg) & $\begin{array}{l}\text { S } \\
\text { P1 } \\
\text { P2 }\end{array}$ & $\begin{array}{l}146 \pm 5 \\
147 \pm 5 \\
143 \pm 6\end{array}$ & $\begin{array}{l}140 \pm 6 \\
141 \pm 5 \\
138 \pm 5\end{array}$ & $\begin{array}{l}-4.1 \\
-4.1 \\
-3.5\end{array}$ & $\begin{array}{l}<0.05 \\
<0.02 \\
<0.077=\text { NS }\end{array}$ \\
\hline LVEDP $(\mathrm{mm} \mathrm{Hg})$ & $\begin{array}{l}\text { S } \\
\text { P1 } \\
\text { P2 }\end{array}$ & $\begin{array}{l}18 \pm 2 \\
15 \pm 2 \\
10 \pm 2\end{array}$ & $\begin{array}{l}19 \pm 2 \\
16 \pm 2 \\
11 \pm 2\end{array}$ & $\begin{array}{l}+7.9 \\
+2.6 \\
+6.9\end{array}$ & $\begin{array}{r}<0.05 \\
\text { NS } \\
\text { NS }\end{array}$ \\
\hline $\begin{array}{l}\text { HR } \times \text { LVsys } \\
\quad\left(\text { beats } / \mathrm{min}^{-\mathrm{mm}_{3}}\right. \\
\left.\mathrm{Hg} \times 10^{3}\right)\end{array}$ & $\begin{array}{l}\text { S } \\
\text { P1 } \\
\text { P2 }\end{array}$ & $\begin{array}{l}10 \pm 0.4 \\
11 \pm 0.5 \\
14 \pm 0.6\end{array}$ & $\begin{array}{r}9 \pm 0.6 \\
10 \pm 0.6 \\
14 \pm 0.6\end{array}$ & $\begin{array}{r}-15.7 \\
-4.6 \\
-3.5\end{array}$ & $\begin{array}{r}<10^{-5} \\
<0.005 \\
\text { NS }\end{array}$ \\
\hline $\begin{array}{l}\mathrm{LV}+\mathrm{dP} / \mathrm{dt} \\
(\mathrm{mm} \mathrm{Hg} / \mathrm{s})\end{array}$ & $\begin{array}{l}\text { S } \\
\text { P1 } \\
\text { P2 }\end{array}$ & $\begin{array}{l}1,652 \pm 92 \\
1,681 \pm 89 \\
1,984 \pm 124\end{array}$ & $\begin{array}{l}1,371 \pm 80 \\
1,479 \pm 76 \\
1,793 \pm 106\end{array}$ & $\begin{array}{l}-17 \\
-12 \\
-9.6\end{array}$ & $\begin{array}{l}<10^{-5} \\
<10^{-5} \\
<0.001\end{array}$ \\
\hline $\operatorname{Vce}_{40}\left(\mathrm{~s}^{-1}\right)$ & $\begin{array}{l}\text { S } \\
\text { P1 } \\
\text { P2 }\end{array}$ & $\begin{array}{l}32 \pm 2 \\
33 \pm 2 \\
41 \pm 3\end{array}$ & $\begin{array}{l}27 \pm 2 \\
29 \pm 2 \\
38 \pm 3\end{array}$ & $\begin{array}{r}-15.6 \\
-12.1 \\
-7.3\end{array}$ & $\begin{array}{l}<10^{-5} \\
<10^{-4} \\
<0.005\end{array}$ \\
\hline Peak Vce $\left(s^{-1}\right)$ & $\begin{array}{l}\mathrm{S} \\
\mathrm{P} 1 \\
\mathrm{P} 2\end{array}$ & $\begin{array}{l}35 \pm 3 \\
38 \pm 3 \\
52 \pm 5\end{array}$ & $\begin{array}{l}29 \pm 2 \\
29 \pm 2 \\
48 \pm 5\end{array}$ & $\begin{array}{r}-17.1 \\
-10.5 \\
-7.7\end{array}$ & $\begin{array}{l}<0.001 \\
<0.001 \\
<0.02\end{array}$ \\
\hline$V \max \left(s^{-1}\right)$ & $\begin{array}{l}\text { S } \\
\text { P1 } \\
\text { P2 }\end{array}$ & $\begin{array}{l}47 \pm 3 \\
49 \pm 3 \\
60 \pm 5\end{array}$ & $\begin{array}{l}41 \pm 2 \\
44 \pm 3 \\
56 \pm 4\end{array}$ & $\begin{array}{r}-12.8 \\
-10.2 \\
-6.7\end{array}$ & $\begin{array}{l}<10^{-4} \\
<0.001 \\
<0.02\end{array}$ \\
\hline $\mathrm{LV}-\mathrm{dP} / \mathrm{dt}(\mathrm{mm} \mathrm{Hg} / \mathrm{s})$ & $\begin{array}{l}\text { S } \\
\text { P1 } \\
\text { P2 }\end{array}$ & $\begin{array}{l}1,965 \pm 96 \\
2,017 \pm 103\end{array}$ & $\begin{array}{l}1,845 \pm 106 \\
1,897 \pm 116\end{array}$ & $\begin{array}{l}-6.1 \\
-5.9 \\
-2.3\end{array}$ & $\begin{array}{l}<0.02 \\
<0.02\end{array}$ \\
\hline $\mathrm{T} 1$ (ms) & S1 & $\begin{array}{l}49 \pm 5 \\
48 \pm 5\end{array}$ & $\begin{array}{l}55 \pm 5 \\
51 \pm 5\end{array}$ & $\begin{array}{r}+12.2 \\
+6.2\end{array}$ & $\begin{array}{l}<0.001 \\
<0.05\end{array}$ \\
\hline $\mathrm{T} 2$ (ms) & $\begin{array}{l}\text { S } \\
\text { P1 }\end{array}$ & $\begin{array}{l}44 \pm 0 \\
38 \pm 3 \\
37 \pm 4\end{array}$ & $\begin{array}{l}42 \pm 4 \\
37 \pm 3\end{array}$ & $\begin{array}{c}+10.5 \\
0\end{array}$ & $<0.01$ \\
\hline & $P$ & & & +6.5 & NS \\
\hline
\end{tabular}

Values are mean \pm standard error of the mean $(n=13)$.

$H R=$ heart rate; HR X LV sys = rate-pressure product; LVsys = left ventricular systolic pressure; LVEDP $=$ left ventricular end-diastolic pressure; $L V+d P / d t=$ peak positive first derivative of $L V$ pressure; $L V$ $-\mathrm{dP} / \mathrm{dt}=$ peak negative $\mathrm{dP} / \mathrm{dt} ; \mathrm{NS}=$ not significant; $\mathrm{P}_{1}=$ low matched pacing; $\mathrm{P}_{2}=$ high matched pacing; Peak Vce $=$ peak measured Vce; $S=$ spontaneous; $T_{1}, T_{2}=$ time constants from biexponential fitting of the LV isovolumic pressure decay; $\mathrm{VCe}_{40}=$ velocity of the contractile element at $40 \mathrm{~mm} \mathrm{Hg}$ total pressure; $V \max =$ Vce extrapolated to $P=0$.

from $2,017 \pm 103$ to $1,897 \pm 116 \mathrm{~mm} \mathrm{Hg} / \mathrm{s}(5.9 \%, \mathrm{p}$ $<0.02)$. Vce 40 decreased $12.1 \%\left(\mathrm{p}<10^{-4}\right)$, peak Vce $10.5 \%(\mathrm{p}<0.001)$ and $V \max 10.2 \%(\mathrm{p}<0.001)$. $\mathrm{T}_{1}$ decreased slightly $(6.2 \%, \mathrm{p}<0.05)$ and $\mathrm{T}_{2}$ did not change.

High matched pacing rate $\left(P_{2}\right)$ : At a matched pacing rate of $98 \pm 3$ beats/min before and after alinidine administration, $\mathrm{LV}+\mathrm{dP} / \mathrm{dt}$ decreased from $1,984 \pm 124$ $\mathrm{mm}$ to $1,793 \pm 106 \mathrm{~mm} \mathrm{Hg} / \mathrm{s}(9.6 \%, \mathrm{p}<0.001)$. Vce 40 decreased 7.3\% $(\mathrm{p}<0.005)$, peak Vce $7.7 \%(\mathrm{p}<0.02)$, and $V \max 6.7 \%(\mathrm{p}<0.02)$. There were no significant changes in either $\mathrm{LV}-\mathrm{dP} / \mathrm{dt}$ or $\mathrm{T}_{1}$ and $\mathrm{T}_{2}$. Coronary flow and $\mathrm{MVO}_{2}$ did not change during matched pacing (Fig. 1, 2 and 3 ).

\section{Discussion}

These findings show that alinidine acts both as a negative chronotropic and negative inotropic agent in patients with coronary artery disease. After alinidine administration, spontaneous HR consistently decreased, accompanied by decreases in indexes of contractility, coronary blood flow, and $\mathrm{MVO}_{2}$. When patients were paced at both low and high matched HRs, the decrease in multiple indexes of contractility persisted. $\mathrm{MVO}_{2}$ measured at the higher pacing rate, however, no longer differed significantly from matched pacing control. Coronary vascular resistance was unchanged during spontaneous or paced HRs.

Kobinger et al $^{1}$ first reported in 1979 that in animal models, alinidine acts as a "specific" bradycardic agent in that its negative chronotropic effect appeared more prominent than its other cardiovascular effects. Millar and Vaughan Williams ${ }^{4}$ showed that alinidine decreased the spontaneous beating rate in isolated rabbit atria. By comparison, in this model, clonidine led to either no change or a slight increase in rate. ${ }^{15}$ This bradycardic action was not related to cholinergic, adrenergic, calcium channel or fast inward current activity. ${ }^{1,5}$ Alterations in alinidine's effects by replacement of extracellular chloride with other anions and intracellular sinoatrial recordings showing a reduction in the slope of slow diastolic depolarization were consistent with a mechanism of anion-selective channel blockade. In man, Kasper et $\mathrm{al}^{16}$ showed that a $40-\mathrm{mg}$ dose of alinidine led to a $23 \%$ increase in PP cycle length with no change in PA, AH or HV intervals or QRS duration.

Brutsaert et al ${ }^{17}$ identified an additional effect of alinidine in rat ventricular cardiac cells that theoretically could account for a change in myocardial performance. In rat ventricular cardiac cells, alinidine delayed the release of calcium from the intracellular membranous system with only minor effects on the total amount 
TABLE III Coronary Flow and Myocardial Oxygen Consumption During Control and After Alinidine Administration

\begin{tabular}{|c|c|c|c|c|c|}
\hline & & Control & Alinidine & $\Delta \%$ & p Value \\
\hline HR (beats/min) & $\begin{array}{l}\mathrm{S} \\
\mathrm{P} 2\end{array}$ & $\begin{array}{l}69 \pm 2 \\
97 \pm 3\end{array}$ & $\begin{array}{l}61 \pm 3 \\
97 \pm 3\end{array}$ & $\begin{array}{c}-11.6 \\
0\end{array}$ & $\begin{array}{r}<0.001 \\
\text { NS }\end{array}$ \\
\hline An (mm Ho) & 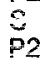 & $\begin{array}{l}100 \div 3 \\
416 \pm 3\end{array}$ & $\begin{array}{l}100 \pm 3 \\
109 \pm 3\end{array}$ & $\begin{array}{l}-7.4 \\
-6.0\end{array}$ & $\begin{array}{l}<0.002 \\
<0.02\end{array}$ \\
\hline $\mathrm{CBF}(\mathrm{ml} / \mathrm{min})$ & $\begin{array}{l}\mathrm{S} \\
\mathrm{P} 2\end{array}$ & $\begin{array}{l}109 \pm 9 \\
122 \pm 9\end{array}$ & $\begin{array}{r}89 \pm 7 \\
110 \pm 8\end{array}$ & $\begin{array}{r}-18.3 \\
-9.8\end{array}$ & $\begin{array}{l}<0.02 \\
<0.071 \text { (NS) }\end{array}$ \\
\hline $\begin{array}{l}\text { CVR (mm } \mathrm{Hg} \\
\mathrm{ml} / \mathrm{min})\end{array}$ & $\begin{array}{l}\mathrm{S} \\
\mathrm{P} 2\end{array}$ & $\begin{array}{l}1.08 \pm 0.10 \\
1.03 \pm 0.10\end{array}$ & $\begin{array}{l}1.20 \pm 0.08 \\
1.05 \pm 0.08\end{array}$ & $\begin{array}{r}+11.1 \\
+2.9\end{array}$ & $\begin{array}{l}\text { NS } \\
\text { NS }\end{array}$ \\
\hline $\begin{array}{l}\text { Art-CS } \\
(\mathrm{ml} / / \mathrm{liter}) \\
\mathrm{MVO}_{2}(\mathrm{ml} / \mathrm{min})\end{array}$ & $\begin{array}{l}\mathrm{S} \\
\mathrm{P} 2 \\
\mathrm{~S} \\
\mathrm{P} 2\end{array}$ & $\begin{array}{l}99 \pm 3 \\
97 \pm 3 \\
11 \pm 1 \\
11 \pm 1\end{array}$ & $\begin{array}{r}101 \pm 3 \\
100 \pm 3 \\
9 \pm 1 \\
11 \pm 1\end{array}$ & $\begin{array}{r}+1.8 \\
+3.8 \\
-17.4 \\
-6.7\end{array}$ & $\begin{array}{r}\text { NS } \\
\text { NS } \\
<0.05 \\
\text { NS }\end{array}$ \\
\hline
\end{tabular}

Values are mean \pm standard error of the mean $(n=12)$.

Art- $\mathrm{CSO}_{2}=$ arterial-coronary sinus difference in oxygen content; CBF = coronary sinus blood flow; $\mathrm{CVR}=$ coronary vascular resistance; $\mathrm{HR}=$ heart rate; $\mathrm{MAP}=$ mean aortic pressure; $\mathrm{MVO}_{2}=$ myocardial oxygen consumption; $\mathrm{NS}=$ not significant; $\mathrm{P}_{2}=$ high matched pacing; $\mathrm{S}=$ spontaneous.

of calcium released or on calcium reuptake, a phenomenon they named activation stabilization. This selective delay in the kinetics of myocardial calcium release could lead to a mechanical asynergy in myocardial function equivalent to the effective decrease in LV performance associated with a diffuse intraventricular conduction defect. ${ }^{18}$ With no effect on electrical recordings, it is possible that a heterogeneous prolongation in the intracellular onset of mechanical activation could lead to a global change in the synergy of $L V$ contraction and, thus, effectively reduce inotropic state.

In patients with coronary artery disease and impaired LV function, Löllgen et $\mathrm{al}^{9}$ observed a $16 \%$ decrease in $\mathrm{HR}$ at rest after a $20 \mathrm{-mg}$ intravenous dose of alinidine. Cardiac output remained unchanged as pulmonary wedge pressure decreased $19 \%$. Systolic pressure decreased 7 to $8 \%$ and systemic vascular resistance did not change. With exercise, alinidine, compared with control, led to increases in stroke volume and cardiac output and a $28 \%$ decrease in pulmonary wedge pressure. Löllgen et al concluded that alinidine had no significant negative inotropic effects and improved cardiac performance during exercise.

Most of our patients did not have significant $\mathrm{LV}$ dysfunction, so it is difficult to compare our results to these data. In addition, we did not measure cardiac output to allow computation of stroke volume.

In patients with unstable angina or myocardial infarction, Simoons and Hugenholtz ${ }^{10}$ found that with intravenous doses of up to $40 \mathrm{mg}$, alinidine led to a $13 \%$
FIGURE 1. Individual and group mean changes in heart rate (HR) and peak positive left ventricular $\mathrm{dP} / \mathrm{dt}(\mathrm{LV}+$ $\mathrm{dP} / \mathrm{dt}$ ) at spontaneous, low matched pacing, and high matched pacing heart rates after alinidine (AI) administration. $L V+d P / d t$ was significantly lower after alinidine at all heart rates. $\mathrm{C}=$ control.
SPONTANEOUS
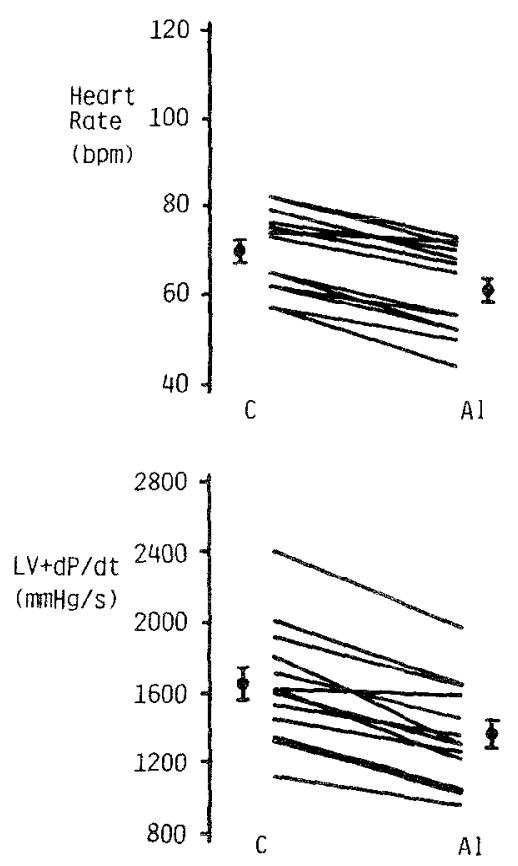

LOW MATCHED $P A C I N G$
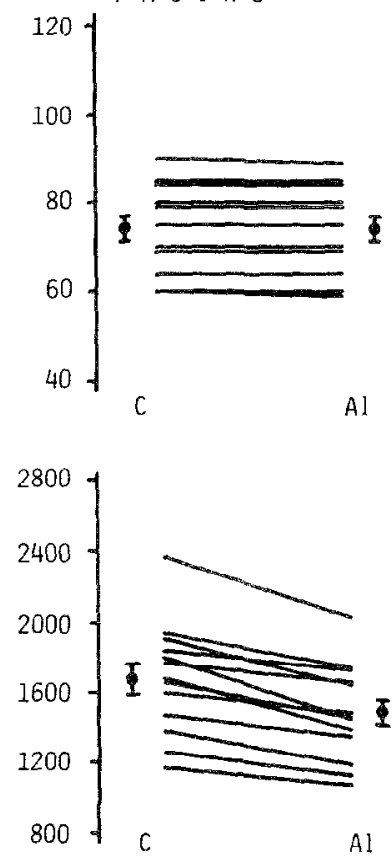

HIGH MATCHED $P A C I N G$

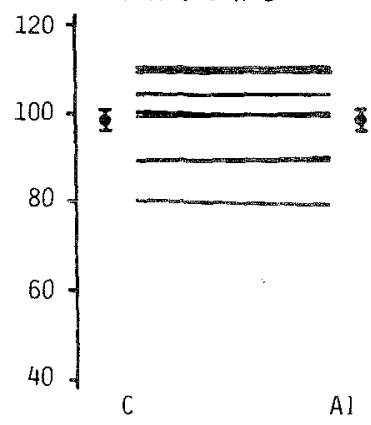

Al

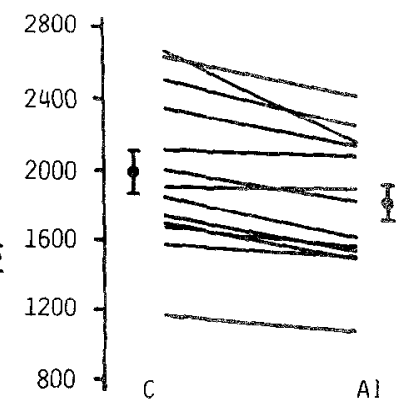



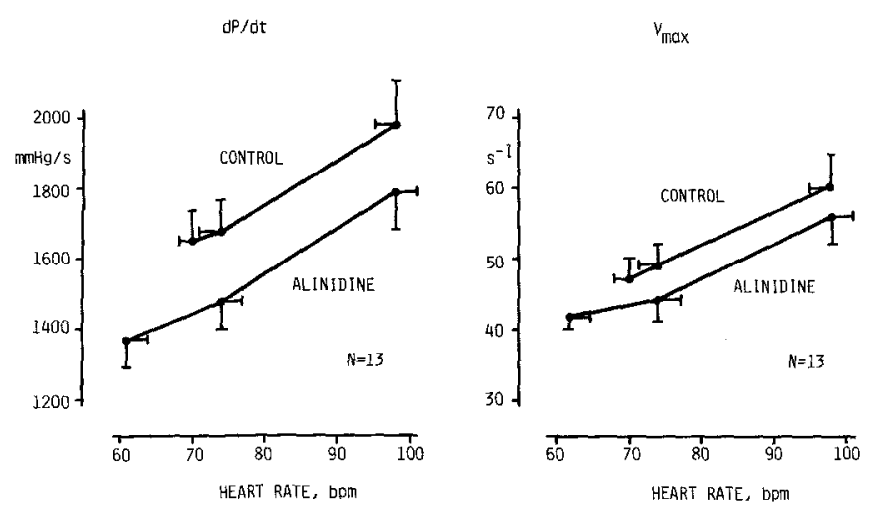

FIGURE 2. Effects of alinidine on indexes of systolic function. Despite matched pacing heart rates, both peak positive left ventricular $\mathrm{dP} / \mathrm{dt}$ $(\mathrm{LV}+\mathrm{dP} / \mathrm{dt})$ and $\mathrm{Vmax}$ remained significantly lower after alinidine administration.

dccrcase in HR. Although mean stroke volume and LV filling pressure did not change, in 3 patients drugassociated signs of heart failure developed, for which the drug was discontinued.

In our study, spontaneous HR decreased $12.9 \%$ after a $0.6-\mathrm{mg} / \mathrm{kg}$ intravenous dose of alinidine, a decrease similar to that reported by other studies. This reduction in HR was accompanied by a $15.7 \%$ decrease in the rate-pressure product and $17.4 \%$ decrease in $\mathrm{MVO}_{2}$.

At matched paced HRs, in almost all patients, multiple indexes of contractility were reduced. The 12.1 and $9.6 \%$ decrease in peak $+\mathrm{dP} / \mathrm{dt}$ observed at low and high matched pacing rates, respectively, is similar to that after intravenous administration of $0.15 \mathrm{mg} / \mathrm{kg}$ of propranolol in patients with coronary artery disease at a constant atrial paced HR. ${ }^{19}$ These changes occurred with no change in LV end-diastolic pressure. At the low matched rate, peak LV systolic pressure and mean aortic pressure were slightly lower. At the high matched rate, peak $L V$ systolic pressure was unchanged and mean aortic pressure was slightly lower. Peak $+\mathrm{dP} / \mathrm{dt}$ is insensitive to changes in afterload ${ }^{20}$ and should not be significantly affected by these minimal decreases in pressure. The uniform decrease in "load-independent" indexes of systolic function also supports the conclusion that the change in systolic function occurred independent of changes in loading.

At spontaneous HR, alinidine decreased the peak rate of $L V$ pressure decline $(-\mathrm{dP} / \mathrm{dt})$ and prolonged the time constants of both early and late isovolumic relaxation. These results would be anticipated from a reduction in HR or inotropic state. When compared at matched HRs, however, there were no differences in these indexes of relaxation with alinidine. This possible dissociation between the effect on LV contractility and relaxation would be unlike that observed with other negative inotropic agents such as calcium channcl blockers, ${ }^{21}$ and could be consistent with the drug's alternative mode of action.

That the decrease in contractility at matched pacing HRs was not associated with a significant decrease in $\mathrm{MVO}_{2}$ is not surprising. Beta blockers also lead to no change in $\mathrm{MVO}_{2}$ at matched paced $\mathrm{HRs}^{22,23}$ This finding is consistent with the hypothesis that the anticipated decrease in $\mathrm{MVO}_{2}$ after a decrease in inotropic state may be offset by an increase in ventricular diameter and systolic wall tension. ${ }^{24}$

Why Löllgen et $\mathrm{al}^{9}$ failed to observe a negative inotropic effect with alinidine in patients with coronary artery disease and LV dysfunction is uncertain. The methods used in their study (right-sided cardiac catheterization) are much less sensitive than those used in

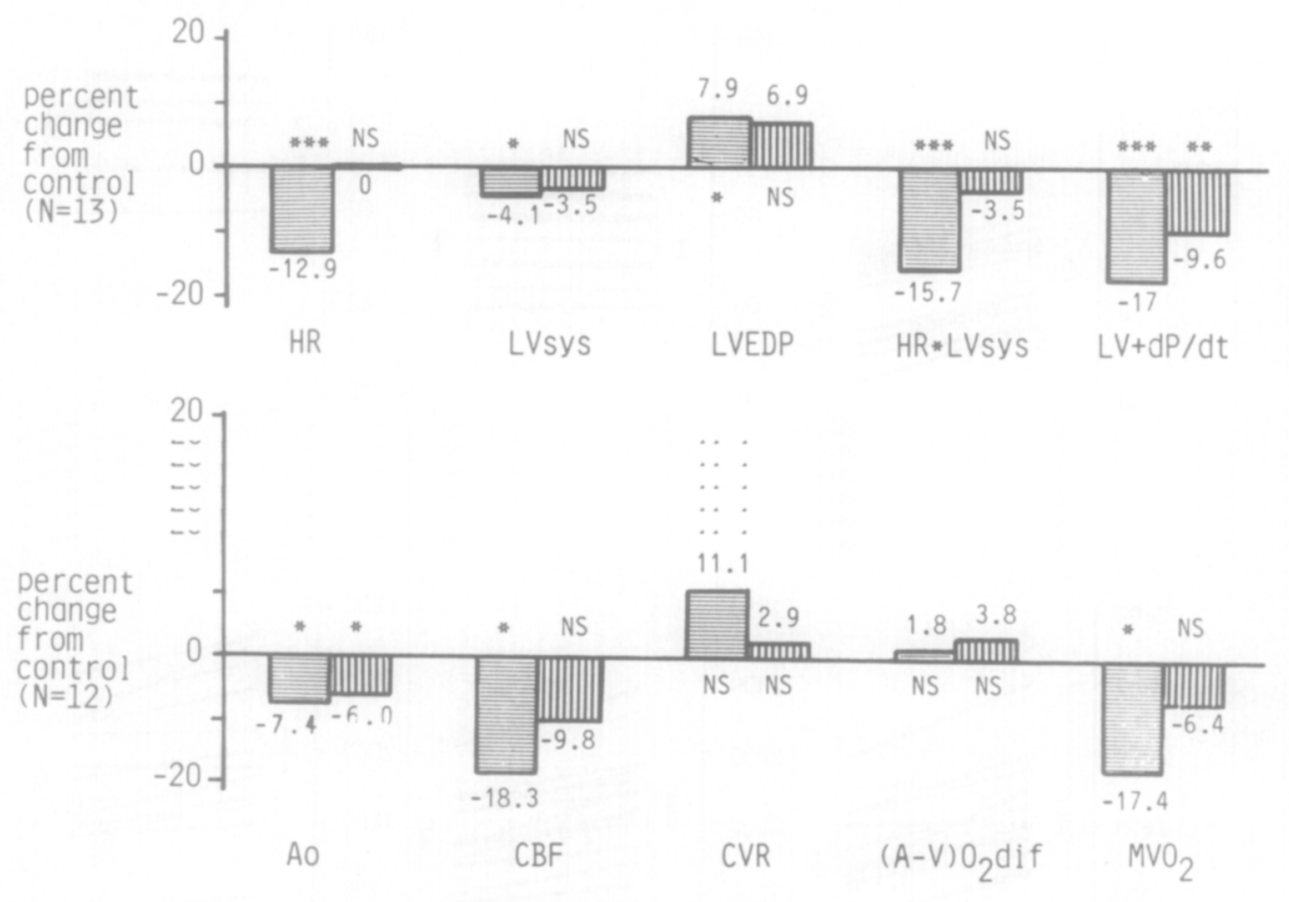

FIGURE 3. Summary of comparative changes in left ventricular (LV) function and coronary hemodynamics after alinidine administration at spontaneous at high matched pacing heart rates (HR). Although changes in indexes of LV function persisted at matched $H R$, there was no significant change in either coronary blood flow or myocardial oxygen consumption $\left(\mathrm{MVO}_{2}\right)$. Ao $=$ mean aortic pressure; $(\mathrm{A}-\mathrm{V}) \mathrm{O}_{2}$ dlff $=$ arterial-coronary sinus difference in oxygen content; $\mathrm{CBF}=$ coronary blood flow; CVR = coronary vascular resistance; HR.LVsys = product of HR.LV peak systolic pressure; $\mathrm{LV}+\mathrm{dP} / \mathrm{dt}=$ peak rate of LV pressure; NS = not significant. 
the present study. That the negative inotropic property may nonetheless be important is confirmed by the finding of Simoons and Hugenholtz ${ }^{10}$ that alinidine did lead to clinical heart failure in several patients with acute severe ischemic heart disease.

Administration of alinidine leads to deted able leveis of the metabolite clonidine after 3 hours that reach low peak levels in 8 to 9 hours. ${ }^{25,26}$ This would not affect the results obtained from this acute study, but could have a pharmacologic effect on sympathetic activity with chronic use.

In stable patients, alinidine could offer an alternative to $\beta$-blocking drug therapy in the presence of atrioventricular block, obstructive lung disease or potential hypoglycemia. In an initial report, when alinidine was compared to the $\beta$-blocker metoprolol in patients with chronic stable angina, both similarly reduced angina symptoms and increased maximal workload with no limiting side effects encounlered with either drug. ${ }^{27}$ Alinidine, however, led to a smaller reduction in HR at rest, maximal exercise $H R$ and maximal exercise ratepressure product. The role of the metabolite clonidine will also have to be assessed, because this agent has also been reported to be beneficial in patients with angina pectoris. ${ }^{28}$

Whether patients with $\mathrm{LV}$ dysfunction can tolerate alinidine better than $\beta$-blocking drugs is uncertain. Theoretically, in patients with severe heart failure requiring inotropic support with catecholamines, alinidine could prevent an undesired tachycardia while relatively preserving inotropic augmentation. ${ }^{29}$ In general, however, any bradycardic and negative inotropic agent is contraindicated in patients critically dependent on sympathetic stimulation in whom cardiac output is maintained by an increased $H R$.

\section{References}

1. Kobinger $W$, Lillie $C$, Pichler L. $N$-allylderivative of clonidine, a substance with specific bradycardic action at a cardiac site. Arch Pharmacology 1979;306:255-262

2. Harron DWG, Jady K, Ridell JG, Shanks RG. Effects of alinidine, a novel bradycardic agent, on heart rate and bloodpressure in man. $J$ Gardiovasc bradycardic agent, on heart rate
Pharmacol $1982 ; 4: 213-220$.

3. Frishman W, Silverman R, Strom J, Ekayam U, Sonnenblick E. Clinical pharmacology of the new beta adrenergic blocking drugs. Part 4. Adverse effects choosing a beta adrenoceptor blocker. Am Heart J 1979;98: $256-262$.

4. Millar JS, Vaughan Williams EM. Anion antagonism-a fifth class of antiarrhythrmic action. Lancet 1981;1:1291-1292.
5. Millar JS, Vaughan Williams EM. Pacemaker selectivity: influence on rabbit atria of jonic environment and of alinidine, a possible anion antagonist. Cardiovasc Res 1981:15:335-350.

6. Schamhardt HC, Verdouw PD, Saxena PR. Improvement of perfusion and function of ischemic porcine myocardium after reduction of heart rate by alinidine. J Cardiovasc Pharmacol 1981;3:728-738.

7. Simoons ML, Tummers $J$, van Meurs van Woezik $H$, van Domburg $A$. Alinidine, a new agent which !omorg hoset rate in pationts with angina poctotis. Eur Heart $\mathrm{J}$ 1982;3:542-545

o. Nieinertz $T$, Kasper W, Meier R, Wiegend U, Bechtold H, Forster I, Pop T, Jahnchen E. Alinidine in angina. Clin Pharmacol Ther 1983;34:770776.

9. Löllgen $\boldsymbol{H}$, Just $\mathbf{H}$, Wollschläger $\boldsymbol{H}$, Kersting F. Hemodynamic actions of alinidine during exercise in patients with coronary artery disease. $Z$ Cardiol $1981 ; 70: 425-428$.

10. Simoons ML, Hugenholtz PG. Hemodynamic effects of alinidine, a specific sinus node inhibitor, in patients with unstable angina or myocardial infarction. Eur Hoart J 1984;5:227 232.

11. Meesler GI, Bernard N, Zeelenberg C, Brower RW, Hugenholtz PG. A computer system for real time analysis of cardiac catheterization data. Cathet Cardiovasc Diag 1975;1:113-132.

12. Brower RW, Meij S, Serruys PW. A mudel of asynchronous left ventricular relaxation predicting the biexponential pressure decay. Cardiovasc Res 1983; 17:482-488.

13. Ganz W, Tamura K, Marcus HS, Donoso R, Yoshido S, Swan HJC. Measurement of coronary sinus blood flow by continuous thermodilution in man. Girculation 1971;44:18\%-195.

14. Arndts D, Stähle M. Development and quality control of a highly sensitive radio-immuno-assay for alinidine. J Pharmacol Method 1981;6:109-120.

15. Kobinger W, Lillie C. Alinidine. In: Scriabine A, ed. New Drugs Annual: Cardiovascular Drugs. Vol. 2. New York; Raven Press, 1984:198-210.

16. Kasper W, Meinertz 1, Treese N, Kersting F, Pop T, Jänchen E. Clinical electrophysiological properties of $\mathrm{N}$ allyl clonidine (ST 567) in man. J Cardiovasc Pharmacol 1981;3:39-47.

17. Brutsaert DL, De Clerck NM, Stanslas US. Activation stabilization: further support for a new class of cardioactive substances. J Cardiovasc Pharmacol 1982;4:808-811.

18. Brutsaert D, Rademakers FE, Sus SU. Triple control of relaxation: implications in cardiac disease. Circulation 1984:69:190-196.

19. Coltart D.J, Aiderman EL, Robison SC, Harrison DC. Effect of propranolol on left ventricular function, segmental wall motion, and diastolic pressure-volume relaxation in man. Br Heart $\mathrm{J} 1975 ; 37: 357-364$

20. Quinones MA, Gaasch WH, Alexander JK. intluence of acute changes in preload, afterload, contractile state, and heart rate on ejection and isovolumic indices of myocardial contractility in man. Circulation 1976;53: 293-302.

21. Serruys PW, Brower RW, Tenkate HT, Bom AH, Hugenholtz PG. Regional wall motion during radiopaque markers after intravenous and intracoronary injections of nifedipine. Circulation 1981;63:584-591.

22. Armstrong PW, Chiong MA, Parker JO. Effects of propranolol of the hemodynamic, coronary sinus blood flow, and myocardial metabolic response to atrial pacing. Am J Cardiol 1977;40:83-89.

23. Kern MJ, Ganz P, Horowitz JD, Gaspar J, Barry WH, Lorell BH, Grossman W. Mudge GH. Potentiation of coronary vasoconstriction by beta-adrenergic blockade in patients with coronary artery disease. Circulation 1983;6: $178-185$.

24. Frishman $W$, Silverman $R$. Clinical pharmacology of the new beta adren ergic blocking drugs Part 2. Physiologic and metabolic effects. Am Heart J 1979:97:797-807.

25. Arndts D, Forster HJ. New aspects in the metabolism of alinidine in man. Eur J Metab Pharmokinet 1981;6:313-315.

26. Harron DWG, Arndts D, Shanks RG. Alinidine pharmokinetics following acute and chronic dosing. Br J Clin Pharmacol 1982;13:821-827.

27. Lubsen J, Bokslag M, Balakumaran K, Simoons ML, van Es GA, Jovanovic $A$, ten Cate $F J$, Pieterse $H$. Anti-anginal effects of the clonidine derivative alinidine: a comparison with metoprolol (abstr). Eur Heart J 1984:5:271.

28. Ceremuzynski L, Zaleska T, Lada W, Zalewsky A. Clonidine effect in chronic angina pectoris. Double-blind, crossover trial on 60 patients. Eur J Cardiol 1979:10:415-427.

29. Julian D. Editor's introductory note. Eur Heart J 1984;5:183. 